\title{
The State, Law and Urban Poverty in Tanzania
}

\author{
By Joe L. P. Lugalla
}

\section{Introduction}

This paper is about the state, law and urban poverty in Tanzania. It seeks to examine how the state in Tanzania via various forms of legislation and policies has been trying to solve the problem of urban poverty.

It begins with a description of the conception of the state about the situation of urban poverty in general and the urban poor in paritcular, and provides a historical account of the kind of policies which the state has been implementing in order to solve the urban question. This is done by analysing both colonial and post-colonial legislation and policies related to the issue. Lastly, the paper discusses in depth the content and practical impact of the famous "Human Resources Deployment Act" of 1983 which is popularly known as "The Nguvu-Kazi Act".

\section{The State's conception of Urban Poverty and the Urban Poor}

A critical analysis of policies, legislation and political statements from some of the leading politicians in Tanzania leads one to the conclusion that the state in Tanzania understands the situation of poverty in terms of poverty itself, and not in terms of the general social relations that characterize and are dominant in the entire social system. The urban poor are seen to be responsible for their situation, they are seen as a social cancer of the city. Such conception and viewpoint is evidenced by the following facts:

Section 176 of the Penal Code deals with what the law terms "Idle and Disorderly Persons". This section has been in the Penal Code since independence. 1

The section identifies seven categories of persons who are defined and deemed by law to be "idle and disorderly persons". Among these are: prostitutes, beggars, gamblers, pimps and others who fall in related groups. 2

1 Legal Aid Committe Pamphlet. Essays on Law and Society, Faculty of Law University of Dar-EsSalaam, 1985, page 74.

2 ibid. 
The seven categories are:

1. Every common prostitute behaving in a disorderly or indecent manner in any public place or loitering or soliciting in any public place for the purpose of prostitution;

2. every person wandering or placing himself in any public place to beg or to gather alms, or causing or procuring or encouraging any child or children so to do;

3. every person playing at any game of chance for money or money's worth in any public place;

4. every person wandering abroad and endeavouring by exposure of wounds or deformation to obtain or gather alms;

5. every person who publicly conducts himself in a manner likely to cause a breach of the peace;

6. every person who without lawful excuse publicly does any indecent act, and

7. every person who in any public place solicits for immoral purposes.

The code states that, anyone convicted of being an "idle and disorderly person" is liable to a fine not exeeding five hundred Tanzanian Shillings or to imprisonment for a period not exceeding three months or to both such fine and imprisonment. 3

Section 177 (1) states that anyone who is convicted twice of the above offence under section 176, is deemed to be a "Rogue and Vagabond", and is liable on the first offence to an imprisonment of three months (without the option of the fine), and on a subsequent offence to an imprisonment of one year. 4

The Written Laws (Miscellaneous Amendments) (No. 2) Act of 1983 amongst other things, amends the Penal Code (Chapter 16 of the Laws) section 176 by adding two more categories to the already existing seven categories of idle and disorderly persons. They are: 5

8. Any able bodied person who is not engaged in any productive work and has no visible means of subsistence; and

3 ibid.

4 ibid. page 75.

5 ibid. 
9. any person employed under lawful employment of any discription who is, without any lawful excuse, found engaged on a frolic of his own at a time he is supposed to be engaged in activities connected or relating to the business of his employment.

To whom does category No: 8 refer to? This category basically refers to people who are unemployed. In practise it means that a person who is unemployed, and is actively seeking employment but cannot get one, is a criminal according to this law and thus subject to either a fine of Tsh. 500/- or 3 months of imprisonment or both. This also includes workers who have been declared redundant and thrown out on the streets for no fault of their own. 6 Thus, as I have already argued, there is no attempt to see the unemployed as victims of the social and economic system as a whole.

In criticising such kind of legislation, the "Legal Aid Committee" of the Faculty of Law at the University of Dar-Es-Salaam has argued that under this law, the unemployed are being "punished" twice. First, by being deprived of employment through which to earn their bread, and secondly by being made criminally liable for the state of unemployment.7

The committee further argues that:

"Politically, it is adding insult to the injury to lump a section of the working class together with gamblers and pimps. Legally, it is a grave folly and an act of desperation to believe that social and economic problems like unemployment can be solved by criminalizing them. And this is besides the insurmountable problems of enforcing such a law and giving a fair and just interpretation of such terms as "productive work", and "visible means of subsistence".8

The ninth category refers to any employed person who absents himself from his work or place or work for reasons not connected with his duties. By doing so, such a person is committing an offence. 9 The practical implications of this code to the urban poor will become clear in our discussion of the "Nguvu-Kazi" Act of 1983. But it is now beginning to be clear that the state's view on the urban poor has, since indipendence been negative.

The post-colonial state inherited this kind of conception from it's predecessor - the colonial state.

$\begin{array}{ll}6 & \text { ibid. } \\ 7 & \text { ibid. } \\ 8 & \text { ibid. } \\ 9 & \text { ibid. page } 76 .\end{array}$ 
Unlike in other colonial African countries, it was until late 1950s that the official colonial state reports began to register concern over the perceptible drift of Africans from upcountry to towns in numbers which bore no relation to the degree of industrial and commercial opportunity offered by the towns, and thus, creating an apparently permanent group of urban unemployed for the first time in major Tanzanian townships. 10 In Dar-EsSalaam a total of 20,000 unemployed was estimated in 1957 of whom only 8,000 were registered.11 Even though, as Armstrong (1987) has argued the control towards rural-urban migration by the colonial state in Tanganyika was markedly less strict and authoritarian than in most neighbouring colonies, such as Kenya, the Rhodesias and Belgian Congo, where pass laws operated to discourage Africans from settling in towns and provided elaborate systems of registering new arrivals using photographs and finger-printing. 12

Earlier on, 1944 the colonial state had enacted a law titled "Townships (Removal of Undesirable Persons) Ordinance" Chapter 104 of the laws. This law empowered the administrative officer for the time being in charge of a district to remove (via a "Removal Order") undesirable persons in the town area under his jurisdiction.

The Ordinance stated that the removal order could be made on any of the following grounds, that is to say, 13

a) that the person has been sentenced to a term of imprisonment (other than in default of payment of fine or compensation) for an offence against the person or in relation to proberty, or for an offence against the Native Liquor Ordinance or the Intoxicating Liquors Ordinance; or

b) that the person has no regular employment or other reputable means of livelihood.

The Law empowered any police officer to arrest without warrant and detain in custody for a period not exceeding one month any person in relation to whom it is proposed to make a removal order, and any person found quilty of an offence against this ordinance was liable to a fine not exceeding two hundred shillings or to imprisonment for a term not exceeding three months or to both such fine and imprisonment. 14

10 Armstrong, A., Urban Control Campaigns in the Third World: The Case of Tanzania. Occasional Paper Series No. 19, Department of Geography, University of Glasgow, 1987, pages 12-13.

11 Tanganyika Standard, 9.7.1957, quoted from Armstrong, A., op.cit. page 13.

12 Armstrong, A., op.cit. page 13.

13 Martin, R., Personal Freedom and The Law in Tanzania: A Study of Socialist State Administration, Oxford University Press (OUP), Nairobi, 1971, page 100.

14 ibid. page 102. 
As Martin (1974: 103) has argued, this ordinance was obviously intended to give the executive the power to deal with what is one of Africa's most serious social problems - the continual influx of large numbers of uneducated, untrained, and therefore unemployed people into urban areas. In other words this ordinance enforced the implementation of the 1923 "Destitute Persons Ordinance" Chapter 41 of the laws whose section 3 (i) read as follows:

"Where it is shown to the satisfaction of a Magistrate that any person is a destitue person, the magistrate may in his discretion order that person:

a) to find a work and to report to the magistrate before a named date;

b) to be detained in custody for a period not exceeding one month with a view to work being found for him; or

c) if he is a native who is not dwelling in his usual place of residence, to return before a named date to his usual place of residence in Tanganyika."

This ordinance defined a "destitue person" as any person without employment and unable to show that he has visible and sufficient means of subsistence.

These statutes were later inherited by the post-colonial state and gave the state the necessary legal powers to remove the destitutes and the unemployed from the cities and towns.

With the presence of these ordinances, it means that the colonial state in Tanganyika had also started exercising some type of control against the process of urbanization.

In 1955 proposals were made requiring every resident to carry a passport or an identity card and this prompted the majority of Africans to rise in revolt.15 It has been argued (Yeager 1983) that such proposals were made precisely because of the emergence of holliganism in which unemployment was believed to be a contributing factor. 16 The police rounded up and repatriated a lot of unemployed people out of Dar-Es-Salaam. Suggestions were also made to enforce people who intended to migrate to Dar-Es-Salaam to pay for a pass which allowed them to migrate and present themselves before the Liwali 's court.17 Other methods of restricting people to migrate to Dar-Es-Salaam included radio broadcasts advising people against travelling to Dar-Es-Salaam in view of the presence of unemployment. 18 Some provisions of the "Colonial Labour Utilization Ordinance" (Chapter 243) of 1947 also

15 Tanganyika Standard, 9.7.1957.

16 Tanganyika Standard, 9.7.1957, Yeager, $R$., "Demography and Development Policy in Tanzania", Journal Of Developing Areas, 16(4), pages 589-610, Armstrong, A., op.cit. page 13.

17 Tanganyika Standard, ibid.

18 Labour Division of Tanganyika 1957, quoted from Armstrong, A., op.cit. page 13. 
restricted and discarded the presence of the unemployed persons in urban areas. Hence all policies emanating from these legislations always focussed on repatriation.

The policy of repatriation was also inherited by the post-colonial state. Commenting on repatriation, President Nyerere (as he then was) observed the following a decade ago:

... it has been announced more times than it is easy to count that every able-bodied person in Tanzania must work ... then on every occasion, their is a great "drive" to round up the unemployed in towns and repatriate them. For a week or so the criminals and idle parasites hide in their houses while responsible workers and peasants on legitimate business are harassed ... Then the whole campaign dies away until it is realised that the problem of criminals in towns and of people not doing a hard day's work is still with us and the process is repeated.19

Confirming Nyerer's observation, the official Daily News Paper of 11th March, 1978 carried the following report on Dar-Es-Salaam:20

Beggars are back in Dar-Es-Salaam once again scarcely three years after they were rounded up in a major swoop in September 1975. According to a survey conducted by the "Daily News" in the past two weeks, the beggars spend nights on pavements of houses belonging to wealthy Asian shopkeepers. Social Welfare authorities have charged that the businessmen use the beggars as watchmen ...

Meanwhile it has been learnt in the course of investigations by this newspaper that over one hundred beggars assemble at an open space along Mrima Street in Kisutu area every night after begging sessions during the day ... An on-the-spot investigation on March the 9th showed that about 60 to 70 beggars, some of them preparing the day's "meal", had already assembled at that area to spend the night. More were expected to join the "congregation".

As Ishumi (1984) has commented, the political party (CCM) paper "Uhuru" of 15th March, 1978, was even more vocal on the matter. Deploying the resurgence of the beggars in the city, the editorial went further in its criticisms of the government for not having found a permanent solution to the problem. 21

19 Nyerere, J., The Arusha Declaration: 10 years after, Dar-Es-Salaam Govemment Printers, 1977, page 46.

20 See also in Ishumi, A.G M., The Urban Jobless in Eastem Africa, Scandinavian Institute of African Studies, Uppsala, 1984, pages 25-26.

21 ibid. 
... The problem of beggars is not a recent one; it is an old problem. Whenever it seemed to go beyond proportions, the "medicine" that has been applied is to round up the victims and to repatriate them to their homes (in the rural areas) ... This method of street-capturing and repatriation relieves the town only for a short while; it is a piecemeal, short-lived solution, for the beggars soon re-appear. We need a more permanent step.

Although the Central Committee of the Party had in 1975 called on the Govemment to look into this problem, and although those concerned promised to give a solution soon including legislating against alms giving nothing has as yet been done and we really wonder why ...

In a country that has declared a socialist policy, it is shameful and indeed inexplicable to find its citizens roaming about in streets begging and rurning garbage bins around in search of food. (Uhuru, March 15th. 1978. Translated from original Swahili by Ishumi 1984: 26)

As if these experiences and criticisms were not enough and teachingwise, the late Prime Minister Ndugu Sokoine, in his budget speech to the Parliament in 1983 directed that:22

"All residents in Dar-Es-Salaam and the other towns in mainland Tanzania who have no work from which to earn a living must return to the villages where they came from or must be given farms outside of Dar-Es-Salaam region, so that an able bodied person works to feed himself and if possible provide the surplus to the nation. Even those with shops, factories, and those rendering services, should be given licences on the condition that they have registered themselves for land allocation so as to produce their own food and alleviate the problem of food shortage in the country. Egually, workers ' families living in towns should grow their own food." (Emphasis added)

In his speech, the Prime Minister estimated at least $40 \%$ of the Dar-Es-Salaam city residents as to be jobless, and that they took a greater share of the national cake. 23

President Nyerer's speech on the Saba Saba day (7.7.1983) gave more weight to the Prime Minister's speech. In this speech, Nyerere gave a notice to the loiterers and other unemployed persons in Dar-Es-Salaam to retum to their respective regions and engage in agricultural production before the govemment started acting on them. 24 Later in his speech

22 Jamhuri ya Muungano wa Tanzania: Hotuba ya Waziri Mkuu Ndugu Edward Moringe Sokoine (Mbunge) kuhusu makadirio ya fedha kwa mwaka 1983/84, Government Printers, 1983, pages 1011.

23 Miti, K., Issues Raised by "Nguvu-Kazi" and its implementation in Dar-Es-Salaam, (mimeo), University of Dar-Es-Salaam, 1983 page 3.

24 ibid. page 4. 
to the Regional Commissioners and Regional Development Directors (RDDS) on the 25th September, 1983, Nyerere equated the loiterers to economic saboteurs and racketeers when the nation had declared a war on them. 25

It is on the basis of such views and conception that the state came out with the "NguvuKazi Act".

However, as it will be demonstrated below, the content, the objectives and the mode of implementation and its effects is a direct replica or carbon paper of the previous colonial and post-colonial strategies of solving urban unemployment problems via repatriation, and restricting excess rural-urban exodus. In order to situate the analysis of "Nguvu-Kazi Act" in its proper historical perspective, a discussion of the nature of post-independent pre "Nguvu-Kazi" period (1961-1983) presents a brief critical evaluation of such policies.

\section{State's Policies on Urban Poverty 1961-1983}

As I have already argued, the "Back to the land Policy" summarized in a single word "Repatriation" has characterized all post-independent policies which have been implemented in order to solve the urban question. Several methods have been used in order to achieve this goal. To mention a few, they include political campaigns like, "Kila mtu afanye kazi" (Every able-bodied person should work), legislations, radio-broadcasts, settlement schemes and ad-hoc round-ups operations.

The 1961 independence did not alleviate the colonial draconian methods of confronting urban poverty, and in a way intensified the previous colonial efforts. 26 Police roundups continued and in 1964, the police officer in charge with the repatriation programme in DarEs-Salaam reported to have dealt with more than 15,000 cases over the previous eight years. 27

A nationwide urban campaign against the urban poor and those intending to migrate to DarEs-Salaam took place in March 1964 with Radio broadcasts carrying messages as follows:

"Those of you who may be thinking of leaving your shambas (farms), stay where you are unless you have quarantee of assured employment in the towns." 28

25 ibid.

26 Armstrong, A., op.cit. page 14.

27 ibid.

28 Tanganyika Infornation Services, 13.3.1964. 
As Armstrong (1987) has argued, the town dwelling unemployed were urged to return to their homes, plant their crops, attend their livestock and become worthy citizens of Tanganyika.29 All the unemployed in urban areas were asked to register themselves voluntarily so that the government could know the number of the people unemployed before it prepared plans to offer them work. 30 Positive measures included the establishment in 1964 of a committee to examine job creation. Settlement schemes especially near DarEs-Salaam were already in operation. A 3,000 acre scheme to settle 200 unemployed on farm allotments had already been opened by the Regional Commissioner. 31 Many of the first recruits into the newly created National Service Programme in 1964 were unemployed youth. 32 Other unemployed were at the same time advised to seek employment in sisal plantations, a work widely known to be hard, unpleasant and poorly paid while waiting for better and well paid jobs. 33 Nevertheless, these campaigns did not help, and at the end of the day the state resumed to her coercive approach after realizing that the rate of unemployment continued to rise unabated. Forced repatriation became the agenda.

With effect from 10th October, 1964, it was declared an offence for the unemployed persons to reside in Dar-Es-Salaam. Under this order, all unemployed people were required to report to the nearest police stations. 34 The police flooded the streets demanding identity cards from suspects, and those who possessed none and were found unemployed were deported to their home areas.

Parallel to these measures, involved the driving away of beggars, destitutes, and strict regulations were introduced in the process of issuing licences to some informal sector activities like petty trading, hawking, shoe-cleaning, knife sharpeners etc. 35 The operation continued although with less momentum. The youth wing of the ruling party (TANU YOUTH LEAGUE/TYL) later joined the operation by assisting the police force in the round-ups of all those who were considered to be unemployed.

Beggars were removed to alms houses, idlers packed off to their home districts (Tanzania Weekly News, 31.3.1967, Armstrong 1987: 16).

Both the campaigns as well as the repatriation operation did not last long, and in a few years to follow the Tanzania Weekly News of 31.8.1967 reported a comeback again of beggars in the streets of Dar-Es-Salaam and the presence of long queues of the unemployed at the labour of fice.

29 Armstrong, A., op.cit. page 14.

30 Reporter, 27.4.1964.

31 Tanganyika Weekly News 31.8.1962, Armstrong, A., op.cit. page 15.

32 Armstrong, A., op.cit. page 15.

33 Reporter, 22.5.1964, Armstrong, A., op.cit. page 15.

34 Tanganyika Standard, 20.10.1964, Armstrong, A., ibid.

35 Tanganyika Standard, 9.10.1964, Armstrong, A., ibid. 
After realizing that the situation was again out of hand, the state announced another campaign in 1967. All urban residents were supposed to possess identity cards. 36 The same procedures were used again, starting with voluntary registration of the unemployed. The govemment advised them to leave the city on their own accord. Later the police started rounding up people by force, this time assisted by special police constables. The state argued that the aim of the campaign operation was to wipe out hard-core criminals. Strict controls on the issuing of licences of petty business re-surfaced. For example water selling business in Dar-Es-Salaam was declared an illegal business and all water sellers were earmarked for repatriation.

Such blunder caused what Armstrong (1987) has termed as the "Battle of Water Sellers" due to an outcry from the public, 100,000 of whom in Dar-Es-Salaam lacked a nearby water source and relied heavily on their services. Due to this outcry, the Minister of Labour intervened and announced a formal reprieve for the water sellers (Armstrong 1987: 16). Again an unemployment committee was established in Dar-Es-Salaam. Villages near urban areas were earmarked for resettlement programmes. Round-ups were haphazardly implemented causing, a lot of sufferings to innocent individuals, and most of the unemployed went into hiding.

Further campaigns were again revised in 1969 and 1970. In April 1970 the police rounded up criminals and several unemployed persons in Dar-Es-Salaam and Tanga. "People who looked suspicious were stopped and questioned about their residences and places of work, and those failing to satisfy the police were arrested" (Tanganyika Standard 1.5.1970, Armstrong 1987: 17)

The press critized the whole operation comparing it with the colonial pass laws, drawing attention to the role of the unemployed as the "scape-goats of society" and expressing the feeling that this task was not being performed as expeditiously as it might be.37 And indeed, as usual, the unemployment problem remained notwithstanding these campaigns and forced repatriation. To some leaders it became clear that a permanent solution to the problem existed outside the urban areas. This is confirmed by one statement in one of Nyerere's speeches where he stressed that;

"The control of rural-outflow would depend largely on the village leadership making rural areas more relevant to youthful aspirations."38

36 Armstrong, A., op.cit. page 16.

37 Sunday News Paper, 5.4.1970.

38 Armstrong, A., op.cit. page 17, Martin, R. op.cit.page 78. 
And already in 1969 the Social Welfare Division of the Ministry of Health had started conducting educational programmes in the rural areas designed to dissuade people from moving to urban centres (Armstrong 1987: 17).

In 1978, the ruling party issued a directive aimed at fighting against the problem of unemployment via the umbrella of the operation "Kila mtu afany kazi". Earlier on in 1976, Nyerer had already declared a "War on Loiterers" (Vita dhidi ya Wazurulaji) (Daily News Paper 26.6.1976). Thus, operation "Kila mtu afanye kazi" was a follow up policy of the previous declared war. The highlights of this war labelled the unemployed as "loiterers" (wazurulaji), "lazy" (wavivu), "drunkards"" (walevi) and "exploiters" (wanyonyaji). They were also regarded as "Maadui wa Siasa ya Ujamaa na Kujitegemea" (Enemies of the Policy of Socialism and Self-reliance). 39 The argument raised against them was that there was no need of having unemployed persons at the time when Tanzania had plenty of free land to work on and for the good of the nation (Daily News 26.6.1976).

The usual procedure of carrying out such operations reappeared starting with voluntary registration to forced round-ups. Plans to resettle the unemployed were envisaged, and several other positive and good promises were made by both government and political leaders. A pilot project to resettle 18,000 jobless residents in Dar-Es-Salaam into more than 30 new villages was initiated.40 It was during this period that sudden new and very famous villages (during that time) like Kibugumo, Tegeta, Mwana-Dilatu and Geza-Ulole emerged in the outskirts of Dar-Es-Salaam city. It has been estimated that the government spent more than 11 million Tanzanian Shillings to resettle the unemployed between 1976-1977.41

This time it is the People's Militia Force (Askari wa Mgambo) who assisted police operations. The round-ups are known to have been harsh, and adhocly planned and implemented thus causing a lot of suffering to innocent urban dwellers. The creation of Kibugumo, GezaUlole villages and others became sensational and the talk of the city. Govemment owned Jazz Bands composed and played dance music which praised the whole operation and the creation of the resettlement villages. The following music sing played by a Jazz Band owned by the Urafiki Textile (Urafiki Jazz Band) dominated and became the tune of the day in Radio-Tanzania programmes.

39 Armstrong, A., op.cit. page 18.

40 ibid.

41 Maro, P. and Mlay, W., "Population Redistribution in Tanzania", in Clarke, J. and Kasinski, L. (Ed), Redistribution of Population in Africa. Heinemann, London, 1982, pages 176-181. 
"Baba na mama, shangazi na mjomba, mji hautufai, twendeni Geza-Ulole. Kibugumo na Kimbiji, Tegeta na Mwana-Dilatu hayo ndiyo makazi ya mwanawakimapinduzi. Biashara ya kahawa, maji, njugu na korosho haitufai, twendeni Kibugumo."

\section{Translation}

(Dear father, mother, aunt and uncle. The city is not good for us, let us go and join Geza-Ulole village. This village, including Kibugumo, Kimbiji, Tegeta and Mwana-Dilatu villages are new residential areas for the revolutionary. The petty businesses of selling coffee, water and nuts is unfit for us. Let us join Kibugumo village.)

Critics of this operation have argued that the resettlement strategy proved administratively cumbersome, was characterized by lack of cooperation among officials involved in the programme, experienced financial difficulties, shortage of building materials, facts which confirm lack of planning, preparations and well conceived policies. 42 Armstrong (ibid) has noted that within a few days after the exercise has begun, the population of some villages dropped to negligible levels.

The majority of the unemployed dispatched in these villages returned to Dar-Es-Salaam indicating a total failure of the 1976 operation. At present the names of these villages belong to the museum of antiquities. People read about them, but none talks of them.

It ist against such background that the "Nguvu-Kazi" act of 1983 has to be understood. One vital question at this point ist; What has been the common characteristics of these prenguvu-kazi policies and strategies? What does one leam from them?

First and foremost is the fact that all the postindependent policies and strategies aimed at combating urban poverty are a replica of the colonial methodology. They differ in form, but they are in actual fact similar in content and essence. Secondly, and in fact related with the first point is the continuation of the viewpoint that the urban poor are responsible for their own situation. Seeing them as a social cancer of the city. The post-independence politics have not been in a position to provide a radical viewpoint quite disimilar to the colonial one. The outcome of this has been the implementation of policies and solutions which confront the symptoms rather than the essence or the cause. Thirdly, is the lack within the modus vivendi of the political system in Tanzania to learn from the previous mistakes and experiences. This is confimed by the reappearance of similar and same mistakes in each campaign, strategy, policy cum operation. In all programmes we have seen that ill-plans, lack of preparations, ad-hoc and haphazard implementation have been dominant. Fourthly, 
there exists a gap of years between one operation and the other, and each operation has always started with a hot heat and then loosing its momentum after few days or months.

Why is this so? Lack of seriousness among political actors can explain the presence of this lacuna. The other reason is precisely because policy planning and implementation in Tanzania has always been carried on ad-hoc basis, and not seriously considered as an ongoing process of the transformation of the overall socio-economic system which calls for the inclusion of urban plans in the overall comprehensive national development plan.

Mlay (1979) argues that these urban control programmes have always proved "temporary, half-hearted, unpopular and inefficient".43 Commenting on the relationship between these urban control campaigns and strategies, Armstrong argues that;

"Urban control measures are often accompanied by, or concide with local drives against crimes, vagrancy or for city cleanliness and civic pride, or nationally instituted initiatives aimed at raising productivity and reducing corruption and ineffieciency. Campaigns, it should be stressed, are often only a well-publicised offensive in a continuous war against the many related urban-based evils which form their target. Thus, regular, if not very thorough steps to detain not only petty criminals but also unemployed appear to form part of the urban police force's normal duties."44

Quoting the study of the ILO (1978), Armstrong argues further conceming the impact of various bureaucratic restrictions on informal sector trade activities, licencing and urban dwellings. Such restrictions, he argues, assist in maintaining continuing pressure on the urban poor.

An interval of about seven years elapsed since the year of the last hot operation in 1976 to 1983 when the government passed another law titled "The Human Resources Deployment (Nguvu-Kazi) Act of 1983" which again necessitated the re-occurence of harsh operations against the unemployed. What is the content of this act? Does it reflect a difference and thus a sense of learning from the previous operations? What are its tenets? And what has been the impact of it on the urban poor? Has it achieved its objectives? The section that follows explores these issues in detail.

43 Mlay, W., "Rural to Urban Migration and Rural Development", in Tanzania Notes and Records, 81 (2), 1977, page 11.

44 Armstrong, A., op.cit. pages 19-20. 


\section{The Human Resources Deployment (Nguvu-Kazi) Act of $\mathbf{1 9 8 3}$}

\subsection{The Act}

The "Nguvu-Kazi" act was passed by Parliament in April and assented by the President in May 1983. The Minister of Labour and Social Welfare was ordered as empowered by the act that the law come into effect on the 15th October, 1983, and the Prime Minister directed the Dar-Es-Salaam city region to start implementing the act before other regions.

The act is divided into 6 main parts. Part one and two deals with the establishment of the "Human Resources Deployment" Scheme and its central administration. In these parts, part II in particular, it is stated that it is the responsibility of local government authority to make arrangements to ensure that every resident within its area of jurisdiction engages in productive or other lawful employment and that it will be upon the authority to formulate properly organized employment generating projects in fields like agriculture, small and large poultry farming and animal husbandry, fisheries, day care centres, small and large scale commercial enterprises. 45

The local governments are also required to:

(i) Make arrangements which will ensure that the undertaking in these projects occupy the residents all year round (Part ii (2) (b)).

(ii) Give guidance and assistance to the agricultural and other sectors on the proper combination of hard work and skill in carrying out their daily functions (Part ii (2) (c)).

(iii)Make arrangements which will cater for proper allocation and use of skilled and high level manpower, their terms of employment in the best economic interest of the nation (Part ii (2) (d)).

Part II Section 8 of the act establishes a national committee known as the "National Human Resources Deployment Advisory Committee" whose role is to advise the Minister upon matters relating to the execution of the national policy on the full deployment of human resources and in particular upon; 46

a) the formulation and coordination of economically viable employment generating schemes suitable for urban and rural areas,

b) making recommendation to the appropriate authorities regarding matters of employment,

45 The Human Resources Deployment Act of 1983, Part II page 99.

46 The Human Resources Deployment Act of 1983, Part II (Section Band 9), page 101. 
c) conducting research in better ways of using the available human resources more productively in government, commercial, industrial and agricultural sectors etc.

Part III of the act establishes the "Local Authority Human Resources Committees" whose functions apart from other directives is to receive, evaluate and carry out the policy and plans laid out by the Minister for the purpose of this act (Part III Section 12).

Part IV section 13 and 14 (which in our case here is very important) deals with the registration of people. This part requires the local government authority to;

(i) Establish and maintain a register to be known as "Employer's Register".

(ii) To maintain a register of all residents who are capable of working in terms of the name of the resident, postal address, age, marital status, number of dependants, parents, residence, level of education, skill possessed, present employment, present residence and name of the residence owner, nationality, originality or adopted domicile.

(iii) Section 15 requires the establishment and maintenance of a register of non-skilled, skilled, and high level manpower who are employed within and outside Tanzania, and that the Embassy offices have to maintain a register of all Tanzanian manpower resident in their areas of jurisdiction.

(iv) Section 16 requires the Minister to establish a system and regulation within which identity cards can be issued to people.

Part V (equally important in respect or this study) deals with the transfer, training and rehabilitation of unemployed persons. 47

This part empowers the Minister to provide a smooth, coordinated transfer and subsequent employment of unemployed residents (Section 17 (i)). In making these arrangements the Minister shall have special regards to the need to secure full deployment of; 48

a) residents who have retired from public service,

b) residents below or above the age of 18 years who still depend on their parents or relatives for their livelihood,

c) law-abiding adult residents who have no known source of income,

d) house-wives, and

e) non citizens

47 The Human Resources Deployment Act of 1983, Part V (Section 17 \& 20) pages 103-4.

48 ibid. 
The Minister is under Part V of this act entrusted to provide facilities for training suited to the residents age, experience, qualification and the provision of rehabilitation courses. 49

Part VI of this act provides some "Miscellaneous Provisions", and section 29 of part vi repeals the "Colonial Labour Utilization Ordinance" of 1947 Chapter 243 of the Laws. The second schedule of the act (pages 106-107) provides the National Human Resources Deployment (Interim Scheme) where a full list of possible considered "legal" economic activities have been outlined, and the local government authority are advised to carry out any of these activities in the furtherance of the provisions of this act.

\subsection{Background ideas to the Act}

Besides the failure of the previous urban control campaigns, the economic crisis whose salient features and impact have already been discussed seems to have been behind the enactment of this act.

The state, besides other factors, seems to have been believing that one of the reasons for the present economic crisis is a result of the fact that a lot of people are not doing productive work, and this is revealed by the low productivity in all sectors of the economy. 50 Such beliefs can be noted from President Nyerere speech in Mtwara on the 7th July, 1982, in which he called upon those people in towns keeping idle dependants to send them home so that they engage in agricultural work.51 Three month later (October 1982) the CCM National Executive Committee instructed the govemment to enact a law that would ensure that any able-bodied person worked.52 During almost the same time, the Ministry of Labour and Social Welfare produced a government paper on how to deploy labour in Tanzania (Uimarishaji wa huduma za Ajira za Taifa Nchini) which served as a basis for cabinet discussion on the issue. 53

In February 1983, the late Prime Minister Ndugu Sokoine made the issue of "Nguvu-Kazi"one of the key aspects of his 8 point programme (Miti 1983). He argued that the government would struggle against poverty through agricultural undertakings by ensuring that every one with exception of children, the aged and disabled as stated in the Arusha Declaration should be engaged in productive work. 54

49 ibid. See also in Miti, $K$., op.cit.

50 Miti, K., op.cit. page 1.

51 ibid.

52 ibid.

53 ibid.

54 ibid. pages 1-2. 
"Every Tanzanian who had the ability to work must meet his/her needs and ensure that he/she contributed surplus to the nation ... He further reiterated that the CCM government will pass a law that ensures that the party order that everybody must work is effectively improved."55 (Daily News, 28.2.1983)

It is against this background that the "Nguvu-Kazi" act was enacted and passed in Parliament in 1983. One may at this juncture ask the following question.

Was the enactment of this act necessary? History shows us that the passing of this act was not necessary, and that its content was not a new phenomenon. Why? and how?

The colonial "Master and Native Servant's Ordinance" of 1923 provided law provisions of controlling and regulating the African migration inflow in towns. The ordinance had also provisions regarding the deployment of human resources. 56 Earlier on in 1913, pass laws were introduced by the colonial government requiring every adult (18 years and above) living in the territory of Tanganyika to have a special card which specified his or her engagement localtiy. In a way, this situation forced some Africans to engage in some economic activities. 57 The Master and Native Servant's Ordinance, which came into force 1924, was enacted in order to enforce the above pass laws. An employee who left his master without lawful excuse and without intentions to return was punished by a fine not exceeding Tsh. 50/-or three months imprisonment. 58

The Master and Native Servant's Ordinance was replaced in 1957 by the Employment Ordinance (Chapter 366 of the laws). This law aimed at safeguarding contracts of employment and at providing work as long as the contract of employment existed. But prior to the enactment of this ordinance, the colonial state passed in 1947 a ley called the "Labour Utilization Ordinance" (Chapter 243 of the laws) with the intention of creating "Labour Utilization Boards" whose function was to facilitate the utilization of available resources of native labour.59

As we have shown previously, compulsory measures to deploy the urban labour force were again taken between 1976-1978 involving the creation of several villages around the outskirts of Dar-Es-Salaam. So, what does this mean in terms of the "Nguvu-Kazi" act?

55 ibid.

56 The Master and Native Servant's Ordinance of 1923.

57 Bisanda, S. S. Z., "Nguvu-Kazi": Its Impact and Implementation in Urban Areas: A Case Study of Dar-Es-Salaam, Unpublished B.A. (Sociology) Degree Dissertation, University of Dar-Es-Salaam, 1985, page 7.

58 ibid.

59 The Labour Utilization Ordinance of 1947, Bisanda, S.S.Z. op.cit. page 7. 
In brief it means that its content as well as the objectives are not a new phenomenon. The act is a replica of the colonial as well as post-colonial measures of dealing with the problems associated with urban poverty. One can ask, what has been the impact of the implementation of this act to both urban and rural areas? Did the implementation of this act benefit from the past experiences? An attempt to answer these questions is the subject matter of the section below.

\subsection{The "Nguvu-Kazi" Act in Practice}

The Prime Minister urged in Parliament that Dar-Es-Salaam region had to start preparation for the implementation of the law by 15 th July 1983, otherwise, nationwide the act became effective in October 1983. According to the Prime Minister, Dar-Es-Salaam was important because $40 \%$ of the city residents (in 1983) were estimated to be unemployed.60

The Minister of Labour and Social Welfare also stressed in his budget speech in 1983 the immediate registration of loiterers, employed people throughout the country and outside the country.61 The registration exercise was to be conducted by ward of fices in urban areas and CCM branches in the rural areas. The Minister stressed also that the responsibility for preparation and supervision of the implementation press was to fall in the hands of local authorities, but directed in the meantime the Regional and Area Commissioners to shoulder the responsibility. 62

The Minister directed that land should be set aside for distribution to those repatriated from the urban areas, though those repatriated would be free to choose either to go back to their home villages or elsewhere in the country. 63

Lastly he insisted in the clearing of the loiterers and disabled people form towns and emphasized the necessity for each person to carry an identification card to avoid repatriation. 64

It was clearly noted form the beginning that most of the authorities concerned with the implementation of this act emphasized on repatriation. The Dar-Es-Salaam Regional Comissioner, while addressing party and govemment leaders of Kinondoni District announced that all residents would be repatriated. 65 Unemployed indigenous residents were

$60 M i t i, K$., op.cit. page 3.

61 ibid.

62 ibid.

63 ibid.

64 ibid.

65 ibid. 
to be provided with work in Goba, Mabwe-Pande, Msogola and Mantu villages around the outskirts of Dar-Es-Salaam.66 Nyerere's speech on the 7th July, 1983, also stressed on repatriation. 67

With emphasis on repatriation the whole "Nguvu-Kazi" programme became to be understood as a measure aimed at clearing the "idlers and disorderly" persons form the urban areas.

Seminars on the issue were organized to leaders and other people who would be involved in the act implementation. The ministry responsible with the act emphasized further the necessity of carrying out seminars at all levels before the law came into operation. 68

As Miti (1983) has noted, the National Executive Committee (NEC) of the party had directed that the implementation of "Nguvu-Kazi" should take place by stages, starting first with the jobless, coming to those employed in petty jobbs, and lastly with those employed in factories and offices.69 It was noted at a seminar on "Nguvu-Kazi" attended by Regional and Area Commissioners that the government had already allocated Tsh. 40million (2 million for each region) for the implementation of the act.

At the end of the seminar, the partipants came out with the following resulutions: 70

a) The target will be on production in order to reduce the current economic difficulties. Every sector of production should make proper plans to enhance the habit of working for a living.

b) Agriculture should be given priority in the efforts to make the country self-reliant-sufficient in food. It should be regarded as a permanent "life and death programme".

c) There should be a general mobilization of the people and means must be found to involve every able bodied person in work ... It should be deemed as an act of liberation and not punishment.

d) Leaders should work hand in hand in order to accomplish the task successfully.

e) The National Human Resources Act should be integrated into the national development programme.

66 ibid.

67 ibid.

68 Uhuru, 20.7.1983.

69 Miti, K., op.cit. page 6.

70 ibid. 
f) There should be no leniency to loiterers. They should be dealt with mercilessly and should not be waxed to join into the programme. Local government authorities should make by laws in this regard (Daily News, 27.9.1983. Emphasis added.)

Miti (ibid) has also noted the following major points emerging form the national interpretation and the project programme procedure of the "Nguvu-Kazi":71

"In the first place "Nguvu-Kazi" is turned into an "operation", a full scale campaign. Campaigns and operations have become permanent features in Tanzania and their mechanisms and effects are well known. This new "operation" had two plongs, that are not quite opposed. The first plong is that of cleaning the towns of the unemployed as a means of easing towns problems. The second plong is to deploy all the available manpower into agricultural production... The second plong is reminiscent of the 1975 campaign of "Kilimo Cha Kufa na Kupona". The first plong is mainly concerned with repatriation. It is not concerned with how those repatriated will be utilized or problems that they are likely to cause in the villages."

Dar-Es-Salaam City Region started implementing the act in July 1983. As usual, a call was made to all the unemployed persons to register voluntarily. Once again "Nguvu-Kazi" was welcomed as the "most ambitious govermment project of the past three years" (Daily News, 15.12.1983). The campaign followed hard on the heels of another dramatic operation to clamp down economic sabotaging, blackmarketing, smuggling and corruption, and was occasionally referred to as a direct follow-up (Daily News, 16.9.1983, Armstrong 1987: 7). On the one hand, stricter enforcement of law and order and tightening lax work discipline was stressed by clearing "bad elements", and, in particular fighting racketeering in which the jobless were often believed to be used as middleman (Daily News, 26.10.1983, Armstrong 1987: 7).

Quotations from the Bible and Koran and exhortations to socialist and nationalist sentiments emphasized the moral necessity of work and castigated "the vagabonds, rogues, and loiterers", and the sins, not only of crime, but also of laziness, parasitism and negligence. 72

On the other hand, other statements stressed the campaign's economic goals by citing the strain which the urban jobless placed on the economy and outlining the positive role they could play in enhancing economic production, particularly during the forth-coming season. 73

71 ibid.

72 Daily News Paper, 28.8.1983.

73 Daily News Paper, 26.9.1983. 
The Daily News Paper of 5th October, 1983, reported that 21, 772 jobless people had been registered voluntarily in Dar-Es-Salaam, and 13,571 in Kagera region, and mainly in Bukoba town. It was also noted that 16,182 people of those registered in Dar-Es-Salaam had indicated their willingness to join villages in Dar-Es-Salaam, and 6,500 acres of land had been secured in the villages surrounding Dar-Es-Salaam and 42,000 acres in the villages away from the city and that there were also 12,503 employees who had registered themselves for farming plots. 74 At the same time the Dar-Es-Salaam regional govemment issued a directive categorizing the nature of legal and illegal petty business activities (see Table 1 below).

Table 1: Legal and Illegal Petty Business in Dar-Es-Salaam in 1983

\section{$\underline{\text { No.Legal }}$}

1. Garages

2. Bars and stores

3. Chicken farming

4. Employment

on casual

terms

(vibarua)

5. Shopowners

\section{$\underline{\text { Legal-But must be licensed }}$}

Hair dressers

Fruit and vegetable selling

(only licensed green grocers)

selling charcoal (only

licensed dealers)

Hairstylists

Tailoring, carpentry, smithing repairing of radios, watches, shoes and electrical goods, selling fire wood, and music recording
Illegal

shoe-shining

selling newspapers

(except licensed agents)

selling "vitumbua", "maandazi", and roasted cassava

in the streets

selling soup and "makongoro" (against health laws)

selling local brew and Konyagi (against the law) and all small vending stalls

Source: Miti, $K$. "Issues Raised by "Nguvu-Kazi" and its implementation in Dar-Es-Salaam. (Mimeo) University of Dar-Es-Salaam 1983. 
On 4th October, 1983, the Dar-Es-Salaam Regional Commissioner announced that all those registered jobless people would start leaving for their home regions by Friday the 14th of October $1983.75 \mathrm{He}$ also expressed hope that those whose jobs were declared illegal would be winding up their business so that they can leave the city (Miti 1983).

According to the Regional Commissioner, the next stage in the implementation of "NguvuKazi" would be on the jobless who did not volunteer to register themselves. On October the 7th. 1983, the Regional Commissioner while speaking to repesentatives of govemment, private and public firms, called upon the employers to ensure that all their employees had identity cards by middle of the month, and ordered that by 15 th. October everybody should not walk in the streets of Dar-Es-Salaam without his identity card (ibid). Furthermore nobody would be allowed into the city without proper documents identifying him as a worker or allowing him/her to come in (ibid).

The police round-ups and nets started on the 17th October, 1983 where 5,724 people were rounded. (1,738 in Temeke District out of which only 295 were detained for further screening) (Table 2).

Table 2: Detention of Unemployed in Dar-Es-Salaam 1983 Campaigns: Two Sample Days

Monday, 17th October 1983:

$\begin{array}{lrrrc}\text { Detained } & 2000 & 1738 & 1986 & 5724 \\ \text { Found to be jobless } & 194 & 295 & 400 & 889 *\end{array}$

Wednesday, 11th Nov. 1984:

Detained $\begin{array}{llll}302 & 600 & 654 & 1724\end{array}$

Found to be jobless

\begin{tabular}{ccrc}
\multirow{2}{*}{ District } & & \\
Kinondoni & Temeke & Ilala & Total \\
& & & \\
2000 & 1738 & 1986 & 5724 \\
194 & 295 & 400 & $889 *$ \\
& & & \\
302 & 600 & 654 & 1724 \\
50 & 98 & 169 & 317
\end{tabular}

* people in this category were apparently those failing to convince the special scrutiny panels of their gainful employment and were to be repatriated to their home districts. However later reports indicated that of this 889 , a further 330 were released after convincing the authorities they were married women, domestic servants or pursued other gainful occupations.

Source: Daily News 19th-22nd October 1983 and 13th/14th Nov. 1983. 
This indiscriminate swoop by the police and militia raised an outcry arising from the public and was criticized for its harshness and harassment. Housewives, domestic servants who were attending familiy matters in town, i.e. buying essentials in shops, markets and some workers with identity cards were arrested and detained in screening centres.

Strict restrictions were again imposed in the licensing of various informal trades to prevent the real jobless from escaping the net by this route (Daily News, 4.11.1983, Armstrong 1987: 11). Threats of demolishing business kiosks used by unlicensed operators were instituted. Confusion among implementors arose. For example, while the business of shoeshining was declared illegal in Dar-Es-Salaam, in Morogoro only $200 \mathrm{~km}$ away this trade was approved and supported by the government officials as gainful employment (Sunday News, 15.12.1983).

The round-up was again repeated on the 27th and 28th October, and in November the swoops had become almost a daily exercise. Having an identity card did not save one from police harassment, and the police as well as the militia force were already advised not to entertain arguments raised by those who had been swooped because that was the task of the scrutinizing panels set up at the district headquarter's level.76

The final stage of the operation involved repatriating those who had been scrutinized to be offenders. As Armstrong has noted, the numbers of those actually repatriated seem to have been very low indeed. By the end of December 1983, only 1,500 people from Dar-EsSalaam had been sent to the rural areas, and the press were already reporting rumours that many were filtering back to the city. 77

\section{The Analysis}

Like the other campaigns and strategies, the implemtation of the "Nguvu-Kazi Act" did not take the advantage of leaming from the abundant problems that dominated and characterized the previous campaigns. The implementation of this act portends poor pre-planning of the whole process. Notwithstanding the appeals and waming from various circles i.e. the press that this was not a once for all exercise, and that more careful, conscientious programme of action was needed in order to avoid past mistakes, the operation made mistakes similar to those in the past. Leaming from past mistakes seems to have gone beyond the wisdom of the policy formulators and implementors. The attitude of the implementing authorities is clearly expressed by the Dar-Es-Salaam Regional Commissioner who

76 Miti, $K$., op.cit. page 11.

77 Daily News Paper, 20.12.1983. 
always used to argue that "We shall learn as we go along". ${ }^{78}$ However, as Miti (op.cit) has argued, "in politics, learning by doing is always a synonym for costly errors and that it is often a painful and on occasion a disruptive process".79 Under "Nguvu-Kazi" it was not a question of leaming from the previous mistakes committed by similar other operations in order to avoid their repetition.

The outcome of leaming as we go along limited the effectiveness of the programme and the officials concerned publically admitted "un-co-ordinated and sometimes haphazardous administration", and decried the different interpretations of the act from one area to another (Daily News, 22.4.1985).80

Armstrong (1987) has argued that both the act and launching of the campaign appear to have been carried through before the authorities were adequately prepared or even before they were conversant with its intentions (page 12).

The police round-ups were not aided by the widespread circulation of identity cards, either forged or no longer legitimate (for example of former workers which had not been surrendered. (Daily News, 4.11.1983).81 It was also reported that some criminals and some unemployed found refugee outside the urban areas in the height of the crackdown and this led in Dar-Es-Salaam to sudden and often unwelcome influxes of new comers in villages close to the city (Daily News, 22.11.1983, Armstrong 1987: 12). Actual figures of the real jobless netted seem to have been very low. The high proportion of innocent detainees as well as harsh and occassionally brutal treatment received from the hands of the police who treated all people as if they were criminals helped, along with the insecurity and disruption created, to alienate public opinion. 82 The programme was also characterized by high corruption by government and police officials rendering the whole exercise useless. 83

One major wealness of the "Nguvu-Kazi" operation concerns its conception of the broader issue of unemployment in Tanzania. The government and party leaders do not see the reason as to why there is unemployment bearing the fact that land is abundant. To them the argument is that anybody who is unemployed in the urban areas can be gainfully employed (can engage) in the agricultural sector. 84 It is on the basis of this fallacy that the urban unemployed are given several insulting names like loiterers, hangers, exploiters and lazy. Agricultural production which is rural based is seen as the answer and solution to urban

78 Miti, K., op.cit. page 11.

79 ibid.

80 Armstrong, A., op.cit. page 12.

81 ibid.

82 Daily News Paper, 29.10.1983.

83 Daily News Paper, 19.10.1983.

84 Miti, K., op.cit. pages 11-12. 
problems, but nobody bothers to critically examine the essence of rampant poverty and underdevelopment that has characterized this sector since the era of colonialism.

Agricultural production is still subsistence based. The methods and tools of production dominant in this sector are still archaic. Cash crop production is still produced in a peasant form of agricultural production, hence the output is minimal and less profitable.85 Rural exploitation, impoverization and pauperization is the order of the day to the extent that the reproduction of the peasant labour is almost impossible under these conditions. It is these contradictions which are behind the rampant process of rural-urban exodus. This is a point abstracted from the reality which both the policy makers and implementors have not yet come to grasp.

The rural-urban exodus continues unabated, and due to the general economic stagnation and the nature of the urban economy fails to absorb employment-wise all the imigrants. The need to survive, forces these imigrants to engage in various dubious economic activities. Most of them resort to joining odd jobs which characterize the informal sector. By imposing strict regulations in licensing informal petty business in urban areas, the "NguvuKazi" exercise has been exacerbating the very problem it aimed to solve. A recent survey of 124 jobless people in Dar-Es-Salaam has revealed that $26(21 \%)$ people depended on relatives, $4(3,2 \%)$ on friends and $94(75,8 \%)$ on operating in informal sector activities. 86 Although this data emanates from a very small sample, the widespread and rapid development of the informal sector activities in Dar-Es-Salaam supports the involvement of the unemployed in this sector. By forcing the unemployed to become peasants, the Act acts negatively to the very beneficiaries of the deployment programme, and denies to acknowledge the fact that life in the rural areas has become unbearable to the majority. By so doing, the act has been treating the symptoms rather than the causes of the so called urban cancer. During colonialism it is the peasant economy which was supposed to reproduce the labour of the urban worker's family. Towns were places for single male workers (Africans). Their families were supposed to remain in the rural areas. "Nguvu-Kazi" urges urban dwellers to send their jobless dependants to the rural areas. 87 The sociology of the African extended family networks and the kind of interdependent relationships which exists within these networks is not put into consideration. Will the resort to the draconian colonial strategy succeed?

The experience of the last 5 years shows concretely that the whole exercise has ended up being a total failure. And it has now become clear that the ideas which link the unemployed as responsible with the present economic crisis are false and misleading. If "Nguvu-Kazi"

85 Miti, K., op.cit. page 12.

86 Bisanda, S. S. Z., op.cit. page 57.

87 Miti, K., op.cit. page 13. 
was prescribed as a solution to the economic crisis that Tanzania is facing, it is clear now that its implementation and further existence cannot alleviate the crisis.

It is true that most of the urban jobless hail from the rural areas. It is also true that labour is needed in the rural areas. But is is doubtful and in fact not true that low productivity in the agricultural sector is a result of rural-urban migration, nor does it guarantee that repatration (back to the rural land policy) will raise rural productivity. Lack of acknowledging these facts led the highly educated Members of Parliament to pass the "Nguvu-Kazi Act" in 1983.

Taking into consideration all the pitfalls that characterizes both the interpretation as well as the implementation of "Nguvu-Kazi", there is no doubt that the act was aimed at reducing the urban population and not economic rehabilitation.

If the later was the case, then plans would have been made to make sure that those repatriated would not face similar problems which forced them to migrate to the urban areas in the first place (Bisanda 1984). What "Nguvu-Kazi" attempted/attempts to do is to simply transfer urban based problems to rural areas. Is this possible?

The answer is definitely no! How can the government expect to succeed in resettling and rehabilitating ablebodied persons in the rural areas when for several times it has failed even to resettle and rehabilitate the very disabled beggars i.e. the blind and the totally physically crippled ones? Another question is; On what issues should "Nguvu-Kazi" have focussed/ focus? The programme should have started by either directing or deploying the jobless in different productive activities, assisting them both morally and materially. If performed well, these activities could generate income to benefit both the producer and the whole nation at large. Projects which assist someone to become self-reliant regardless as to whether they are urban or rural based could form a positive point of departure. Practically, this could be implemented by promoting rural and urban enomies and employment opportunities through the promotion of small scale industrial operations. Instead of the present habit by the Small Scale Industrial Development Organization (SIDO) of concentrating on urban based light consumer goods industries, i.e. those producing baby playing toys, household utensils, electric hot plates and bulbs, SIDO should be urged to invest and produce agricultural inputs which can lead to the revolutionization of the productive capacity of the rural sector.

Nguvu-Kazi is supposed to recognize and assist the operations of the informal sector activities. Further to that there is an urgent need to operationalize (nationwide) a structural transformation of the existing economic system. A new industrial strategy which creates backward and forward linkages between the various sectors of the economy, such as an industrial strategy which not only provides employment opportunities but also aids the process of transforming the rural sector. 


\section{Concluding Remarks}

In this paper we have dealt with the question of State politics, law and poverty. Such scheme has not been chosen by accident but rather intentionally. The aim of the article has been to examine the reaction of the state towards the situation of urban poverty. The politics propounded by the State in order to change the situation of urban poverty have since the colonial period called for the passing of laws to ensure practical implementation. Thus our inclusion of several legal material in this paper has been a matter of necessity rather than of choice.

Overall we have seen throughout the paper that the state has always understood and continues to understand the causes of urban poverty in terms of poverty itself.

Poverty is not seen as a reflection of the way how the entire social economic and political system is organized. The choice of solutions propagated by the state to solve urban poverty ends up treating the symptoms rather than the causes underneath the problem. Often it is these politics which exacerbate the very problems they are aimed to solve.

Our opinion is that law, like any other state policies in Tanzania has to aid the process of development, if development is seen in terms of people's freedom and participation in deciding crucial matter which affect their lives, presence of democracy human dignity and rights, and the social and economic well being of the standard of living. Law should be in favour of assisting the poor rather than criminalizing them. Coercive laws, like the "NguvuKazi Act" of 1983 exacerbate the problems rather than solving them. 


\title{
A Note on Privatization of State Enterprises in Ghana
}

\author{
By Joseph R.A. Ayee
}

Ghana's Provisional National Defence Council (PNDC) has resorted to the policy of privatization as an antidote to the dismal performance of state enterprises in the country. The article examines the privatization policy of the PNDC and argues that state intervention in the economy is justified and necessary. In the writer's view, privatization does not necessarily improve the viability of state enterprises, since it is fraught with numerous problems.

\section{The State Law and Urban Poverty in Tansania}

\section{By Joe L.P. Lugalla}

This paper is about the state, law and urban poverty in Tanzania. The paper examines how the state in Tanzania has been trying to solve the problem of urban poverty. The main argument is that the state's conception of urban poverty is not realistic. The urban poor are seen as responsible for their poverty. This is confirmed by the kind of coercive policies, legislation and other measures which have been instituted by the state in order to solve the problem. The paper argues that due to lack of a critical analysis of the causes of poverty, the state has been implementing policies which have exacerbated the problem, because they have treated the symptoms rather than the essential relations. The paper concludes by arguing that law, like other policies, has to assist the process of social and economic development. Rather than criminalizing the poor, in developing socialist countries like Tanzania law has to assist them.

\section{Property Rights and Agricultural Development. \\ The Land Issue in Equatorial Guinea}

\section{By Bernd Holznagel, Cord Jakobeit}

This paper illustrates the argument that land rights in Africa evolve in response to changing political, social and economic conditions. The case of Equatorial Guinea has more in common with the situation in other former Spanish colonies in America than with the typical African situation. A system of individual titles to the land, orderly registration and 